\title{
The effect of piperine pre-conditioning on the pharmacokinetics of orally administered marbofloxacin in rats
}

\author{
Vipul B. Chauhan, Chirag M. Modi*, Urvesh D. Patel, and Harshad B. Patel \\ Department of Pharmacology and Toxicology, College of Veterinary Science and Animal Husbandry, Junagadh \\ Agricultural University, Junagadh, India
}

\begin{abstract}
CHAUHAN, V. B., C. M. MODI, U. D. PATEL, H. B. PATEL: The effect of piperine pre-conditioning on the pharmacokinetics of orally administered marbofloxacin in rats. Vet. arhiv 90, 69-75, 2020.
\end{abstract}

\begin{abstract}
The present study was carried out to evaluate the effect of piperine pre-conditioning on the pharmacokinetics of marbofloxacin in Wistar rats. Marbofloxacin was administrated at a dose rate of $5 \mathrm{mg} / \mathrm{kg}$ body weight alone, and along with piperine pre-conditioning at a dose of $10 \mathrm{mg} / \mathrm{kg}$ of body weight, orally for 5 days in Wistar rats. The mean values of the half-life $\left(\mathrm{t}_{1 / 2}\right)$, maximum drug concentration $\left(\mathrm{C}_{\max }\right)$ and area under the curve (AUC) were $1.19 \pm 0.17 \mathrm{~h}$, $2.71 \pm 0.09 \mu \mathrm{g} / \mathrm{mL}$ and $12.25 \pm 0.77 \mu \mathrm{g} . \mathrm{h} / \mathrm{mL}$, respectively, in piperine pretreated rats. The values were significantly higher than the values observed in rats administered with marbofloxacin alone $(1.12 \pm 0.31 \mathrm{~h}, 2.28 \pm 0.20 \mu \mathrm{g} / \mathrm{mL}$ and $9.24 \pm 0.59 \mu \mathrm{g} . \mathrm{h} / \mathrm{mL}$, respectively). The drug clearance $\left(\mathrm{Cl}_{\mathrm{B}}\right)$ in piperine pretreated rats was $0.04 \pm 0.02 \mathrm{~L} / \mathrm{h} / \mathrm{kg}$, which was significantly lower than the clearance rate of the drug $(0.53 \pm 0.03 \mathrm{~L} / \mathrm{h} / \mathrm{kg})$ in the animals administered with marbofloxacin alone. The study reveals that piperine has a significant effect on the pharmacokinetics of marbofloxacin, which may be due to an increase in the drug absorption and inhibition of elimination of the drug in rats.
\end{abstract}

Key words: piperine pre-conditioning; pharmacokinetics; marbofloxacin; Wistar rats

\section{Introduction}

Antibacterial agents are important drugs as they are frequently used to treat various infectious diseases. Increasing bacterial resistance is due to lower absorption of drugs and the failure to achieve the therapeutic drug concentration. To solve this problem, the dose rate of the antimicrobial agent has to be increased, which may lead to an increase in adverse effects. A bio-enhancer with antimicrobial agents may be useful to increase the bioavailability of drugs. Piperine is an active component of Piper longum L. and Piper nigrum L. which has bio-enhancing property when given along with antibacterial drugs (HIWALE et al., 2002). Pretreatment with piperine has been shown to increase the rate and extent of absorption of some of drugs widely used in human medicine, which are moderately absorbed on their own by enhancement of the blood supply through vasodilatation, inhibition of their metabolism, or inhibition of renal clearance (ATAL, 1979). An important role played by piperine in metabolism is the inhibition of hepatic monooxygenase and UDP-glucouronyltransferase, intestinal glucouronidation, and inhibition of CYP3A4 and p-glycoprotein (BHARDWAJ et al., 2002).

\footnotetext{
*Corresponding author:

Assist. Prof. Dr. C. M. Modi, Department of Pharmacology and Toxicology, College of Veterinary Science and Animal Husbandry, Junagadh Agricultural University, Junagadh-362 001, (Gujarat) India, E-mail: chiragvets@yahoo.co.in
} 
Marbofloxacin is a bactericidal agent with broad spectrum of activity against Gram-negative, some Gram-positive bacteria and Mycoplasma spp. The in vivo and in vitro efficacy of the drug against Staphylococcus intermedius, Escherichia coli, Proteus mirabilis, Pseudomonas spp., Pasteurella multocida, and Mannheima haemolytica have been reported (SHOJAEE and LEES, 1997; SPRENG et al., 1995). Evaluation of the pharmacokinetics of marbofloxacin in various animal species has revealed that the drug is poorly absorbed in animals following oral administration. Notwithstanding its broad spectrum of activity, its therapeutic effectiveness is altered by its poor bioavailability through the oral route. One practical approach to enhance its bioavailability is using herbal bio-enhancers with the antibacterial agents. It would be rational and judicious to study the pharmacokinetics of newer antimicrobial drugs with bio-enhancers such as piperine. The continued interest in marbofloxacin has led to several recent investigations describing its pharmacokinetics in various species of domestic animals, such as cattle (BELEW et al., 2015), goats (SIDHU et al., 2010), horses (BOUSQUET-MELOU et al., 2002), poultry (DE LUCAS et al., 2005), dog (HEINEN, 2002) camels (LACHGUER et al., 2013) and rabbits (CARPENTER et al., 2006). The effect of piperine on the pharmacokinetics of ciprofloxacin and norfloxacin was studied by BHISE and PORE (2002) and JANAKIRAMAN MANAVALAN (2008). However, data are not available in relation to the effect of piperine pre-conditioning for five days on the pharmacokinetics of marbofloxacin in rats.

\section{Materials and methods}

Experimental animals. In this study, twelve male albino Wistar rats (Rattus norvegicus) of 10-12 weeks of age and $250 \pm 10 \mathrm{~g}$ in weight were obtained from Cadila Pharmaceutical Pvt. Ltd., Dholka, Ahmedabad, Gujarat. They were maintained as per the guidelines of the Committee for the Purpose of Control and Supervision of Experiments on Animals. The experimental protocol, including the number of rats and the various procedures involved, was approved by the Institutional Animal Ethics Committee (No. JAU/JVC/IAEC/SA/08/16).
Animal husbandry. The rats were housed in standard polypropylene cages at room temperature between 23 to $26^{\circ} \mathrm{C}$, and relative humidity ranging from 40 to $55 \%$. A twelve hour light-dark cycle was maintained in the animal room. Rat pelleted feed (VRK biological system, Vadodara, Gujarat, India) containing $18 \%$ protein was provided for the animals.

Drug and chemicals. Marbofloxacin technical grade powder was obtained from Sigma Aldrich, USA. Marbofloxacin tablets $(50 \mathrm{mg})$ and marbofloxacin injections $(100 \mathrm{mg} / \mathrm{mL}, 30 \mathrm{~mL}$ multi dose vials) were used in the study. Piperine was procured from Sigma Aldrich, Bangalore, India. Water, acetonitrile and formic acid of HPLC grade were purchased from S. D. Fine Chem. Ltd., and Merck India Ltd., Mumbai.

Experimental design. Twelve albino rats were equally divided through randomization with minimum variations in body weight $( \pm 10 \%)$ into two groups of 6 animals each. Rats in group I were treated with a single oral dose of marbofloxacin ( 5 $\mathrm{mg} / \mathrm{kg})$ and in group II with piperine $(10 \mathrm{mg} / \mathrm{kg}$, PO for 5 days), followed by single oral dose of marbofloxacin ( $5 \mathrm{mg} / \mathrm{kg}, \mathrm{PO})$.

Drug administration and collection of samples. Marbofloxacin and piperine were administered by oral route using a graduated syringe with an intubation cannula at the dose of 5 and $10 \mathrm{mg} /$ $\mathrm{kg}$ body weight, respectively. Blood samples (approximately $0.250 \mathrm{~mL}$ ) were collected from the retro orbital plexus under light anesthesia. Following oral administration of marbofloxacin, blood samples were collected at 0 minute (before drug administration), 5 (0.083 h), 15 (0.25 h) and 30 $(0.5 \mathrm{~h})$ minutes and at $1,2,4,8,12$ and $24 \mathrm{~h}$. Plasma was separated after centrifugation (Eppendorf 5430 $\mathrm{R}$, Germany) of blood samples at 14000 revolutions per minute (rpm) for 10 minutes at $4{ }^{\circ} \mathrm{C}$. The plasma samples were transferred to cryo-vials (2 $\mathrm{mL}$ capacity) and then stored at $-20{ }^{\circ} \mathrm{C}$ until being assayed for marbofloxacin concentration using HPLC.

Marbofloxacin assay. Plasma concentrations of marbofloxacin were determined by High Performance Liquid Chromatography (HPLC), with a slight modification of the flow rate of the mobile phase described by CARPENTER et al. (2006). 
High performance liquid chromatography apparatus by Schimadzu (Japan)-LC-2010 CHT, comprising a quaternary gradient delivery pump (LC-2010) and a UV detector was used for assay. Chromatographic separation was performed using a reverse phase $\mathrm{C} 18$ column (Thermo, ODS; $250 \times 4$ $\mathrm{mm}$ ID, 5 micron) at $30^{\circ} \mathrm{C}$. HPLC data integration was performed using LC solution software (Shimadzu).

The mobile phase was a mixture of $10 \mathrm{mM}$ formic acid (80\%) and acetronirile (20\%), and the $\mathrm{pH}$ of 5.1 was adjusted with ortho-phosphoric acid. The mobile phase was filtered through $0.45 \mu$ size filter paper (Millipore India Pvt., Ltd., Bangalore) and degassed by ultra-sonication. The mobile phase was pumped into the column at a flow rate of 0.75 $\mathrm{mL} /$ minute. The effluent was monitored at $295 \mathrm{~nm}$ wavelength.

The plasma samples were deproteinized using perchloric acid. Briefly, $100 \mu \mathrm{L}$ of $0.8 \mathrm{M}$ perchloric acid was added to $100 \mu \mathrm{L}$ of each plasma sample. After mixing for 2-3 minutes, the samples were centrifuged at $12000 \mathrm{rpm}$ for 10 minutes. The clean supernatant was collected in an HPLC vial with insert. Twenty microliters of the supernatant was injected intothe HPLC system for analysis through an auto sampler.

For standardization, a stock solution of marbofloxacin was prepared initially by adding $1 \mathrm{mg}$ pure marbofloxacin powder to $1 \mathrm{~mL}$
HPLC water. The known standard solutions of marbofloxacin for constructing the calibration graph were prepared by serial dilution of a stock standard solution in HPLC water and the drug free plasma of the rats. The stock solution was used to prepare standard marbofloxacin concentrations of $0.039,0.078,0.156,0.312,0.625,1.25,2.5,5,10$, and $20 \mu \mathrm{g} / \mathrm{mL}$. Each standard prepared in plasma was then treated by the steps described earlier for extraction of marbofloxacin. Twenty microliters of supernatant was injected through the auto sampler into the HPLC.

Pharmacokinetic analysis and statistical analysis. The pharmacokinetic parameters were calculated on the basis of the plasma concentration of marbofloxacin after its single dose oral administration at $5 \mathrm{mg} / \mathrm{kg}$ of body weight in the piperine pretreated rats and alone, according to the formulas described by BAGGOT (1977) and GIBALDI and PERRIER (1982). All data obtained are presented as mean \pm standard error (SE). Data were analyzed statistically by student's $t$-test (using Microsoft Office Excel ${ }^{\circledR}$ software) to observe differences between the treatment groups.

\section{Results}

The mean plasma drug concentrations at different time points, following a single oral dose administration of the marbofloxacin alone $(5 \mathrm{mg} /$ $\mathrm{kg})$ and along with piperine pre-conditioning (10 $\mathrm{mg} / \mathrm{kg}$, PO for 5 day) in rats, are depicted in Fig. 1.

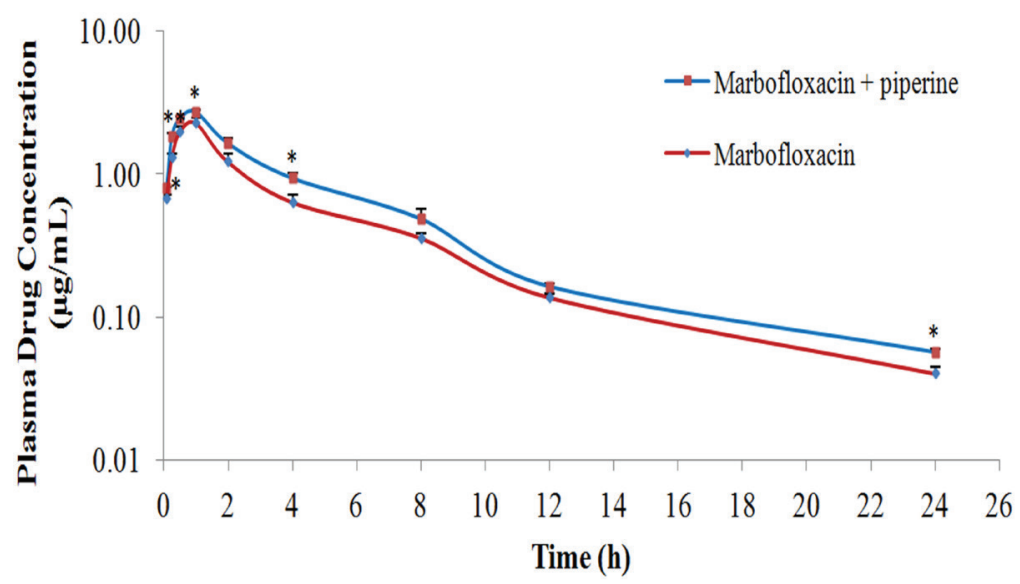

Fig. 1. Semi-logarithmic plot of concentrations of marbofloxacin in plasma versus time after oral administration $(5 \mathrm{mg} / \mathrm{kg})$ alone and along with piperine pre-conditioning $(10 \mathrm{mg} / \mathrm{kg}$ oral for 5 days $)$ in rats. *Significant at $\mathrm{P}<0.05$ 
V. B. Chauhan et al.: The effect of piperine pre-conditioning on the pharmacokinetics of orally administered marbofloxacin in rats

The pharmacokinetic parameters of marbofloxacin, following single oral dose administration of the marbofloxacin alone and along with piperine pre- conditioning (10 mg/kg, PO for 5 day) in rats, are presented in Table 1 .

Table 1. Comparison of the pharmacokinetic parameters (Mean \pm SE) of marbofloxacin after oral administration (5 $\mathrm{mg} / \mathrm{kg})$ alone and along with piperine pre-conditioning $(10 \mathrm{mg} / \mathrm{kg}$ oral for 5 days $)$ in rats $($ Mean $\pm \mathrm{SE}, \mathrm{n}=6)$

\begin{tabular}{|c|c|c|c|}
\hline $\begin{array}{c}\text { Pharmacokinetic } \\
\text { parameter }^{\mathrm{a}}\end{array}$ & Unit & $\begin{array}{c}\text { (Group I) } \\
\text { Marbofloxacin alone }\end{array}$ & $\begin{array}{c}\text { (Group II) } \\
\text { Piperine pre-treatment + Marbofloxacin }\end{array}$ \\
\hline B & $\mathrm{h}^{-1}$ & $0.13 \pm 0.01$ & $0.12 \pm 0.01$ \\
\hline$t_{1 / 2 \beta}$ & $\mathrm{h}$ & $5.54 \pm 0.40$ & $5.94 \pm 0.41$ \\
\hline $\mathrm{A}^{\prime}$ & $\mathrm{h}^{-1}$ & $0.86 \pm 0.22$ & $0.65 \pm 0.10$ \\
\hline$t_{1 / 2 \alpha_{-}}$ & $\mathrm{h}$ & $1.12 \pm 0.31$ & $1.19 \pm 0.17$ \\
\hline $\mathrm{Ka}$ & $h^{-1}$ & $3.03 \pm 0.58$ & $3.59 \pm 0.41$ \\
\hline $\mathrm{t}_{1 / 2 \mathrm{Ka}}$ & $\mathrm{h}$ & $0.26 \pm 0.04$ & $0.20 \pm 0.02$ \\
\hline $\mathrm{C}_{\text {max }}$ & $\mu \mathrm{g} / \mathrm{mL}$ & $2.28 \pm 0.20$ & $2.71 \pm 0.09 *$ \\
\hline$\overline{\mathrm{T}}_{\max }$ & $\mathrm{h}$ & $0.92 \pm 0.08$ & $1.00 \pm 0.00$ \\
\hline $\mathrm{AUC}_{\left(0_{-} \mathrm{t}\right)}$ & $\mu \mathrm{g} . \mathrm{h} / \mathrm{mL}$ & $9.24 \pm 0.59$ & $12.25 \pm 0.77 * *$ \\
\hline $\mathrm{AUC}_{(0-\infty)}$ & $\mu \mathrm{g} . \mathrm{h} / \mathrm{mL}$ & $9.58 \pm 0.56$ & $12.74 \pm 0.73^{* *}$ \\
\hline AUMC & $\mu \mathrm{g} . \mathrm{h}^{2} / \mathrm{mL}$ & $54.98 \pm 0.39$ & $73.95 \pm 2.90^{* *}$ \\
\hline MRT & $\mathrm{h}$ & $5.83 \pm 0.50$ & $5.85 \pm 0.22$ \\
\hline $\mathrm{Vd}_{\text {(area) }}$ & $\mathrm{L} / \mathrm{kg}$ & $4.29 \pm 0.50$ & $3.46 \pm 0.36$ \\
\hline $\mathrm{Vd}_{(\mathrm{ss})}$ & $\mathrm{L} / \mathrm{kg}$ & $3.14 \pm 0.42$ & $2.34 \pm 0.08$ \\
\hline $\mathrm{Cl}_{(\mathrm{B})}$ & $\mathrm{L} / \mathrm{h} / \mathrm{kg}$ & $0.53 \pm 0.03$ & $0.40 \pm 0.02 * *$ \\
\hline
\end{tabular}

*Significant at $\mathrm{P}<0.05,{ }^{*}$ Highly significant at $\mathrm{P}<0.01,{ }^{a}-\beta$, elimination rate constant; $\alpha$ - distribution rate constant; $\mathrm{A}^{\prime}$ - intercept of absorption phase; Ka - absorption rate constant; $\mathrm{t}_{1 / 2 \mathrm{ka}}$ - absorption half-life; $\mathrm{t}_{1 / 2 \mathrm{a}}$ - distribution half-life; $\mathrm{t}_{1 / 2 \beta}$ - elimination half-life; $\mathrm{C}_{\max }$ - the peak or maximum plasma concentrations; $\mathrm{T}_{\max }$ - the time to reach peak or maximum plasma concentration; AUC - area under the plasma concentration - time curve; AUMC - area under the moment curve; MRT - mean resident time; $\mathrm{Vd}_{\text {(area) }}-\mathrm{volume}$ of distribution; $\mathrm{Vd}_{(\mathrm{ss})}$ - volume of distribution of drug at steady-state; $\mathrm{Cl}_{(\mathrm{B})}$ - total body clearance of drug

\section{Discussion}

In the present study, the maximum marbofloxacin concentration $\left(\mathrm{C}_{\max }\right)$ observed in the piperine pretreated group was significantly $(\mathrm{P}<0.05)$ higher than that observed in animals treated with the drug alone. Similarly, a higher plasma drug level $\left(\mathrm{C}_{\max }\right)$ of $8.0 \pm 0.34 \mu \mathrm{g} / \mathrm{mL}$ at $1.0 \pm 0.22 \mathrm{~h}$ after oral administration of ampicillin along with piperine $(10 \mathrm{mg} / \mathrm{kg})$ in rats was reported by HIWALE et al. (2002). The findings of the present study are in agreement with report by PATEL et al. (2011), who observed higher concentrations $\left(\mathrm{C}_{\max }\right)$ of gatifloxacin when it was administered with piperine.

Following oral administration of marbofloxacin in piperine pre-treated rats, the plasma levels of the drug were significantly higher at $0.08333,0.25,0.5$ and $4 \mathrm{~h}(\mathrm{P}<0.05)$ than those values obtained after single oral administration of marbofloxacin alone. The present finding was similar to an earlier report that mentioned higher plasma concentrations of marbofloxacin in piperine pretreated rats throughout its entire absorption phase, which might be due to increased permeability into the gastro intestinal tract epithelium cell membrane (ANNAMALAI and MANAVALAN, 1989). However, the minimal detectable level of drug $(0.04 \pm 0.005 \mu \mathrm{g} / \mathrm{mL})$ in the group administered with marbofloxacin alone did not differ significantly $(\mathrm{P}>0.05)$ from the level $(0.06 \pm 0.00 \mu \mathrm{g} / \mathrm{mL})$ observed in the piperine pretreated group. 
A non-significantly lower value of the apparent volume of distribution $\left(\mathrm{Vd}_{\text {area }}\right)$ was observed in the piperine pretreated group as compared to the only marbofloxacin group. The finding is supported by the finding of a similar volume of distribution in layer birds $(3.33 \pm 0.083 \mathrm{~L} / \mathrm{kg})$ following the oral administration of gatifloxacin along with piperine co-administration (PATEL et al., 2011). A non-significant difference was observed in the elimination half-life and mean residence time (MRT) in the piperine pretreated group as compared to those of the only marbofloxacin group.

The higher values of AUC and AUMC in piperine treated rats were indicative of the enhanced systemic availability of marbofloxacin, which might be due to suppression of the drug's metabolizing activities. Piperine, the active principle of $P$. longum, has been shown to inhibit drug metabolizing activities (REEN et al., 1997). Piperine has shown a bio-enhancing effect on the absorption of co-administered drugs such as sulphadiazine, pyrazinamide, rifampin, isoniazid in human volunteers (ZUTSHI, 1985). The present findings are supported by previous reports by HIWALE et al., (2002) and PATEL et al., (2011) who observed higher values of AUC in rats (17.80 $\pm 0.41 \mu \mathrm{g} . \mathrm{h} / \mathrm{mL})$ and layer birds $(17.54 \pm 0.20 \mu \mathrm{g} . \mathrm{h} /$ $\mathrm{mL})$, following oral administration of amoxicillin and gatifloxacin with piperine, respectively.

A significantly lower value of total body clearance in piperine pretreated rats was observed as compared to rats administered with marbofloxacin alone. This finding is in agreement with the clearance of gatifloxacin $(0.57 \pm 0.00$ $\mathrm{L} / \mathrm{h} / \mathrm{kg}$ ) reported, following its oral administration along with piperine co-administration, in layer birds (PATEL et al., 2011). This result indicates the comparatively slower clearance of marbofloxacin following oral administration in piperine pre-treated rats, and suggests the higher tubular reabsorption of the drug and excretion of the drug through glomerular filtration.

In the present study, the observations related to the longer elimination half-life of the marbofloxacin in piperine pre-treated rats are similar to those reported by SINGH et al. (2005), who documented the longer elimination half-life of oxytetracycline
$(6.37 \pm 0.44 \mathrm{~h})$ in hens after its administration along with piperine. The elimination half-life of marbofloxacin following single oral administration in the piperine pre-treated rats is similar to the value of the elimination half-life $\left(\mathrm{t}_{1 / 2 \beta}\right)$ of gatifloxacin (4.03 $\pm 0.09 \mathrm{~h})$ after oral administration in layer birds (PATEL et al., 2011). This increase in the elimination half-life of marbofloxacin indicates the inhibitory effect of piperine on the elimination phase due to a decrease in renal clearance (SRINIVAS et al., 2008). Alterations in the pharmacokinetic profile of marbofloxacin by piperine pre-conditioning might be due to the increased permeability of the gastro intestinal tract epithelial cell membrane, inhibition of drug metabolizing enzymes and suppression of the first pass metabolism of the marbofloxacin by piperine.

\section{Conclusion}

Piperine pre-conditioning altered the maximum drug concentration, the area under the curve, the area under the moment curve and total body clearance of marbofloxacin after oral administration in rats.

\section{References}

ANNAMALAI, A. R., R. MANAVALAN (1989): Effects of Trikatu and its individual components and piperine on gastrointestinal tract: Trikatu - A bioavailability enhancer. Indian Drugs, 27, 595-604.

ATAL, C. K. (1979): A breakthrough in drug bioavailability - A clue from age old wisdom of Ayurveda. IMDA Bulletin, $10,483-484$.

BAGGOT, J. D. (1977): Principles of Drug Disposition in Domestic Animals. The Basis Of Veterinary Clinical Pharmacology. $1^{\text {st }}$ ed., W.B. Saunders Co., Philadelphia, U.S.A. pp. 144-189.

BELEW, S., J. Y. KIM, M. A. HOSSAIN, J. Y. PARK, S. J. LEE, Y. S. PARK, J. W. SUH, J. C. KIM, S. C. PARK (2015): Pharmacokinetics of marbofloxacin after intravenous and intramuscular administration in Hanwoo, Korean native cattle. J. Vet. Med. Sci. 77, 327-329

DOI: $10.1292 /$ jvms.14-0221

BHARDWAJ, R. K., H. GLAESER, L. BECQUEMONT, U. KLOTZ, S. K. GUPTA, M. F. FROMM (2002): Piperine, a major constituent of black pepper, inhibits human P-glycoprotein and CYP3A4. J. Pharmacol. Exp. Ther. 302, 645-650.

DOI: $10.1124 /$ jpet.102.034728 
BHISE, S. B., V. Y. PORE (2002): Influence of co administration of piperine on pharmacokinetic profile of ciprofloxacin. Indian Drugs 39, 166-168.

BOUSQUET-MELOU, A., S. BERNARD, M. SCHNEIDER, P. L. TOUTAIN (2002): Pharmacokinetics of marbofloxacin in horses. Equine Vet. J. 34, 366-372.

DOI: $10.2746 / 042516402776249191$

CARPENTER, J. W., R. P. HUNTER, J. H. OLSEN, H. HENRY, R. ISAZA, D. E. KOCH (2006): Pharmacokinetics of marbofloxacin in blue and gold macaws (Ara ararauna). Am. J. Vet. Res. 67, 947-950.

DOI: $10.2460 /$ ajvr.67.6.947

DE LUCAS, J. J., C. RODRIGUEZ, S. WAXMAN, F. GONZALEZ, I. URIARTE, M. I. SAN ANDRES (2005): Pharmacokinetics of marbofloxacin after intravenous and intramuscular administration to ostriches. Vet. J. 170, 364368.

DOI: $10.1016 /$ j.tvj1.2004.06.012

GIBALDI, M., P. PERRIER (1982): Noncompartmental analysis based on statistical moment theory. In: Pharmacokinetics. $2^{\text {nd }}$ ed. New York: Marcel-Dekker Inc. pp. 409-417.

HEINEN, E. (2002): Comparative serum pharmacokinetics of the fluoroquinolones enrofloxacin, difloxacin, marbofloxacin, and orbifloxacin in dogs after single oral administration. J. Vet. Pharmacol. Ther. 25, 1-5.

DOI: $10.1046 /$ j.1365-2885.2002.00381.x

HIWALE, A. R., J. N. DHULEY, S. R. NAIK (2002): Effect of co-administration of piperine on pharmacokinetic of $\beta$-lactam antibiotics in rat. Indian J. Exp. Biol. 40, 277-281.

JANAKIRAMAN, K., R. MANAVALAN (2008): Studies on effect of Piperine on oral bioavailability of ampicillin and norfloxacin. Afr. J. Tradit. Complement. Altern. Med. 5, 257-262.

DOI: 10.4314 /ajtcam.v5i3.31281

LACHGUER, M. A., A. MOKHTARI, R. OBELAHCEN, I. ATTIFI, M. LAURENTIE, A. EL HRAIKI (2013): Pharmacokinetic disposition of marbofloxacin and danofloxacin in camel (Camelus dromedarius). J. Camel Pract. Res. 20, 245-250.
PATEL, S., S. DEVADA, H. PATEL, N. PATEL, S. BHAVSAR, A. THAKER, (2011): Influence of Co-administration of piperine on pharmacokinetic profile of gatifloxacin in layer birds. Global Veterinaria 7, 427-432.

DOI: $10.1080 / 00071668.2012 .682724$

REEN, R. K., F. J. WIEBEL, J. SINGH, J. SINGH (1997): Piperine inhibits aflatoxin B1 induced cytotoxicity and genotoxicity in V79 Chinese hamster cells genetically engineered to express rat cytochrome P450 2B1. J Ethnopharmacol. 58, 165-173.

DOI: 10.1016/s0378-8741(97)00104-9

SHOJAEE, A. F., P. LEES (1997): Pharmacodynamic and pharmacokinetic inter-relationships of antibacterial drugs. J. Vet. Pharmacol. Ther. 20, 14-17.

SIDHU, P. K., M. F. LANDONI, F. S. ALIABADI, P. LEES (2010): PK-PD integration and modeling of marbofloxacin in sheep. Res. Vet. Sci. 88, 134-141.

DOI: 10.1016/j.rvsc.2009.05.013

SINGH, M., C. VARSHNEYA, R. S. TELANG, A. K. SRIVASTAVA (2005): Alteration of pharmacokinetics of oxytetracycline following oral administration of Piper longum in hens. J. Vet. Sci. 6, 197-200.

SPRENG, M., J. DELEFORGE, V. THOMAS, B. BOISRAMÉ, H. DRUGEON (1995): Antibacterial activity of marbofloxacin. A new fluoroquinolone for veterinary use against canine and feline isolates. J. Vet. Pharmacol. Ther. 18, 284-289

DOI: 10.1111/j.1365-2885.1995.tb00592.x

SRINIVAS, N., L. NARASU, P. B. SHANKAR, R. MULLANGI (2008): Development and validation of a HPLC method for simultaneous quantitation of gatifloxacin, sparfloxacin and moxifloxacin using levofloxacin as internal standard in human plasma: application to a clinical pharmacokinetic study. Biomed. Chromatogr. 22, 1288-1295.

DOI: $10.1002 / \mathrm{bmc} .1060$

ZUTSHI, U. (1985): Herbals as enhancer of bioavailability of antimicrobials. Indian J. Pharma. 17, 120-127.

Received: 21 April 2018

Accepted: 13 August 2019

CHAUHAN, V. B., C. M. MODI, U. D. PATEL, H. B. PATEL: Učinak pretkondicioniranja piperinom na farmakokinetiku peroralno primijenjenog marbofloksacina u štakora. Vet. arhiv 90, 69-75, 2020.

SAŽETAK

U ovom je radu istražen učinak pretkondicioniranja piperinom na farmakokinetiku marbofloksacina Wistar štakora. Marbofloksacin je apliciran u dozi od $5 \mathrm{mg} / \mathrm{kg}$ tjelesne mase peroralno, samostalno i nakon pretkondicioniranja 
piperinom u dozi od $10 \mathrm{mg} / \mathrm{kg}$ tjelesne mase peroralno tijekom 5 dana. U štakora tretiranih piperinom prosječne vrijednosti poluživota $\left(\mathrm{t}_{1 / 2}\right)$ bile su $1,19 \pm 0,17 \mathrm{~h}$, maksimalna koncentracija lijeka $\left(\mathrm{C}_{\max }\right) 2,71 \pm 0,09 \mu \mathrm{g} / \mathrm{mL}$, a površina ispod krivulje (AUC) 12,25 $\pm 0,77 \mu \mathrm{g} . \mathrm{h} / \mathrm{mL}$. Navedene vrijednosti bile su znakovito više od onih utvrđenih u štakora tretiranih samo marbofloksacin $(1,12 \pm 0,31 \mathrm{~h}, 2,28 \pm 0,20 \mu \mathrm{g} / \mathrm{mL}$ i $9,24 \pm 0,59 \mu \mathrm{g} \cdot \mathrm{h} / \mathrm{mL})$. Klirens lijeka $\left(\mathrm{Cl}_{\mathrm{B}}\right) \mathrm{u}$ štakora tretiranih piperinom bio je $0,04 \pm 0,02 \mathrm{~L} / \mathrm{h} / \mathrm{kg}$ što je bilo znakovito niže od klirensa lijeka $(0,53 \pm 0,03 \mathrm{~L} / \mathrm{h} /$ kg) u životinja koje su dobivale samo marbofloksacin. Ovo istraživanje pokazuje da piperin znakovito utječe na farmakokinetiku marbofloksacina, što može biti posljedica povećane apsorpcije lijeka i inhibicije uklanjanja lijeka u štakora.

Ključne riječi: pretkondicioniranje piperinom; farmakokinetika; marbofloksacin; Wistar štakori 
